\title{
Wood characteristics of Terminalia amazonia, Vochysia guatemalensis and Hyeronima alchorneoides planted in Costa Rica
}

\author{
Características de la madera de Terminalia amazonia, Vochysia guatemalensis y \\ Hyeronima alchorneoides plantadas en Costa Rica
}

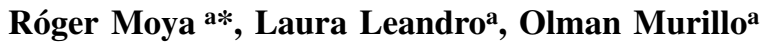 \\ *Corresponding author: aEscuela de Ingeniería Forestal, Instituto Tecnológico de Costa Rica, Apartado 159-7050, \\ CIIBI-ITCR, Cartago, Costa Rica, tel.: +506 55024 33, fax: +506 59133 15, rmoya@itcr.ac.cr
}

\begin{abstract}
SUMMARY
The aim of the present study was to evaluate the esthetic and structural characteristics, as well as the wood decay resistance of Terminalia amazonia, Vochysia guatemalensis, and Hyeronima alchorneoides trees from fast-growth condition in a tropical humid region of Costa Rica. A total of 10 trees of T. amazonia, V. guatemalensis and H. alchorneoides each, were randomly selected for harvesting from forest plantations. Young trees of all three species showed very poor esthetic characteristics in comparison to market expectations, particularly due to their reduced heartwood content and their light dark color. Wood from plantation forest trees of V. guatemalensis, T. amazonia, and H. alchorneoides in Costa Rica showed inferior wood properties than wood from natural forests. However, age differences of trees between both provenances limit the validity of present results. Terminalia amazonia from forest plantations show very promising characteristics for industry processes due to its ease of drying, manipulation, and mechanical properties. The natural durability of species (young or mature) from humid regions of Costa Rica can be increased by means of preservation techniques such as the vacuum-pressing method, which are very convenient particularly in young trees with high content of sapwood.
\end{abstract}

Key words: decay resistance, preservation, native species, mechanical properties.

\section{RESUMEN}

El objetivo del presente estudio fue evaluar las características estéticas, físicas y mecánicas, así como la durabilidad natural de la madera de Terminalia amazonia, Vochysia guatemalensis y Hyeronima alchorneoides provenientes de árboles creciendo en plantaciones de rápido crecimiento en la región del trópico húmedo de Costa Rica. Un total de 10 árboles por especie de T. amazonia, V. guatemalensis y H. alchorneoides fueron seleccionados aleatoriamente y cortados como material para determinar las propiedades de la madera. Se encontró que la madera de este tipo de árboles presentaba baja calidad estética en comparación con la madera comúnmente usada en el mercado de este tipo de especie del bosque natural. Ello porque poseen poca cantidad de duramen y su color es claro. La madera de árboles creciendo en condiciones de rápido crecimiento de $V$. guatemalensis, T. amazonia y H. alchorneoides en Costa Rica mostró propiedades inferiores que la madera proveniente de los bosques naturales. Sin embargo, la diferencia de edad entre las procedencias es la causante de los resultados. T. amazonia de plantaciones mostró características promisorias para procesos industriales debido a su facilidad de secado, preservación y relativamente altas propiedades mecánicas de su madera. La durabilidad natural de estas especies de árboles jóvenes en el trópico húmedo de Costa Rica puede ser incrementada por la preservación de la madera utilizando el método vacío presión, particularmente debido al alto contenido de albura que es fácil de tratar con preservante.

Palabras clave: durabilidad natural, preservación, especies nativas, propiedades mecánicas.

\section{INTRODUCTION}

Costa Rica and other countries in Central America posses a great stock of hardwood timber for sawmilling both from natural as well as from plantation forests (Moya 2004). However, just a few native species have acquired commercial importance in reforestation projects due to a reduced knowledge on their genetic, reproductive, and silvicultural management (Mora 2002). By year 2000, only
5,000 ha of native species were counted for forest plantations with production purposes, limiting the establishment of a sustainable wood trade market.

Relatively fast-grown native species (with rotation periods shorter than 40 years) such as Terminalia amazonia (J. F. Gmel.) Exell., Vochysia guatemalensis (J. D. Smith) Standl., Hyeronima alchorneoides Allemão, Bombacopsis quinata (Jacq.) Dugand., Alnus acuminate Kunth., and Cordia alliodora (R. et P.) Oken. have shown excellent results 
in plantation forestry in Costa Rica (Murillo et al. 2001, Pérez and Kanninen 2001, Petit and Montagnini 2001). In the last 5 years, native species have gained importance in commercial reforestation on account of their excellent performance in pure and mixed plantations (Piotto et al. 2003, Alice et al. 2004). A promising productivity, the inclusion of abandoned areas to the economic activity, nutritional benefits to soil fertility, agroforestry and silvopastoril system development, carbon sequestration, among others, are very encouraging factors promoting at present the reforestation with native species in the country (González and Fisher 1994, Montagnini 2000, Petit and Montagnini 2001).

Terminalia amazonia, V. guatemalensis and $H$. alchorneoides are species widely planted in the country due to their outstanding adaptation to different soil conditions (Montagnini and Porras 1998, Montagnini 2001, Piotto et al. 2003). In Costa Rica, these species have been planted predominantly in the Atlantic and South Pacific regions under tropical humid climate by commercial reforestation projects at a rate of $10 \mathrm{ha} /$ year (Solis and Moya, 2004abc). These annual reforestation rate represented a total production of 4,000 ha (only for the mentioned species) by year 2003, showing a great potential for the local industry as wood suppliers (Moya 2004). Both the civil construction sector and the furniture sector in Costa Rica are very familiar with their wood characteristics. Moreover, T. amazonia and $H$. alchorneoides are widely known in the Tropical American wood markets because of their vast geographical distribution.

Just a few studies on wood properties of forest species from humid tropical climates are reported in the literature and are limited to a reduced number of characteristics. Butterfield et al. (1993) carried out a study on the radial variation of the basic density, the fiber length and vessel area from pith to bark in H. alchorneoides and V. guatemalensis, comparing trees grown in natural conditions with those grown in plantations. González and Fisher (1998) studied the specific gravity, fiber length, vessel density, and vessel radial diameter from pith to bark in natural forests of $V$. guatemalensis in Costa Rica, while Moya (2000) evaluated the sawmilling process of 6-year-old T. amazonia trees from fast-growing plantations in Costa Rica.
The aim of the present study was to evaluate the esthetic and structural characteristics, as well as the decay resistance of $T$. amazonia, $V$. guatemalensis and H. alchorneoides young trees planted in a tropical humid region of Costa Rica.

\section{METHODS}

Site. In 1994 a trial of native species was established in San Carlos, Alajuela (North Atlantic region of Costa Rica), specifically at coordinates $10^{\circ} 21^{\prime} 29.60^{\prime \prime} \mathrm{N}$ and $84^{\circ} 31^{\prime}$ 23.36" W Hyeronima alchorneoides, V. guatemalensis and T. amazonia trees were planted in an area classified as very humid tropical forest (Holdridge 1967). The region shows a mean annual rainfall of $3,077 \mathrm{~mm}$, with a mean temperature of $26.9^{\circ} \mathrm{C}$ and two dry months (Calvo et al. 1996).

Plantation description and tree sampling. Three different pure plantations located one next to the other were selected for the study. The initial planting density was 1,111 trees/ha ( $3 \times 3 \mathrm{~m}$ spacing); at the moment of evaluation the stands aged 9.0 years and presented a density of 495-575 trees/ha (table 1).

A total of 10 trees per species (H. alchorneoides, $V$. guatemalensis and T. amazonia) were randomly selected for harvesting. A stem section from the base up to 1.3 $\mathrm{m}$ high was obtained from each tree. In addition, crosssectional disks $3.0 \mathrm{~cm}$ thick were taken from at base, at breast height $(1.3 \mathrm{~m})$, and every $2.5 \mathrm{~m}$ thereafter up to a minimum stem diameter of $13.0 \mathrm{~cm}$ over bark (minimum commercial diameter considered for these species in Costa Rica). The North-East direction was marked on each stem cross-section for later identification in the laboratory. First, heartwood mean diameter was calculated as the average of two cross-sectional measurements on each stem section. Second, average diameter (with and without bark) was calculated following the same procedure. Next, heartwood, sapwood and bark cross-sectional area $\left(\mathrm{cm}^{2}\right)$ was calculated as a geometric circle.

Table 1. Characteristics of plantation used to study.

Características de las plantaciones usadas para el estudio.

\begin{tabular}{|c|c|c|c|c|c|}
\hline \multirow[b]{2}{*}{ Species } & \multirow{2}{*}{$\begin{array}{l}\text { Stand density } \\
\quad(\text { trees/ha) }\end{array}$} & \multirow{2}{*}{$\begin{array}{l}\text { Average total height } \\
\qquad(\mathrm{m})\end{array}$} & \multirow{2}{*}{$\begin{array}{l}\mathrm{DBH} \\
(\mathrm{cm})\end{array}$} & \multicolumn{2}{|c|}{ MAI } \\
\hline & & & & $\mathrm{DBH}(\mathrm{cm})$ & $\begin{array}{c}\text { Total height } \\
(\mathrm{m})\end{array}$ \\
\hline Terminalia amazonia & 495 & 17.8 & 14.5 & 1.6 & 2.0 \\
\hline Hyeronima alchorneoides & 486 & 16.9 & 15.7 & 1.7 & 1.9 \\
\hline Vochysia guatemalensis & 575 & 26.3 & 21.9 & 2.4 & 2.9 \\
\hline
\end{tabular}

$\mathrm{DBH}=$ average diameter at breast height; $\mathrm{MAI}=$ average medium annual increment. 
Esthetic properties. The IAWA standards for hardwood species were used for describing color, smell, taste, texture, shine, and wood grain (IAWA-Committee 1989).

Physical and mechanical properties. A diametral section of $3.0 \mathrm{~cm}$ wide was cut along the center (including the pith) of each disk and divided into two sub samples (cut in half) for studying the physical wood properties. Specific gravity was determined using both sub samples. The volume of each sample was defined as the volume of water it displaced when submerged, according to ASTM standard norms (ASTM 2003a). The wood density was calculated as green mass divided by green volume, while the specific gravity was calculated as oven-dry weight ( $105^{\circ} \mathrm{C}, 48$ hours) divided by green volume.

The logs taken from the base of the tree up to $1.3 \mathrm{~m}$ high were used for determining the static bending (modulus of rupture and modulus of elasticity), the compression parallel to grain (maximum crushing stress), shear parallel to grain (maximum shearing stress), and side Janka hardness. A total of 20 samples per species were prepared for each test following ASTM D-143-94 standards (ASTM 2003b).

Air drying properties. Each log (from the base of the tree to $1.3 \mathrm{~m}$ high) was sawed and pilled for drying in boards of different thickness $(1.25 \mathrm{~cm}, 2.50 \mathrm{~cm}, 3.75 \mathrm{~cm}$, $5.00 \mathrm{~cm}, 6.25 \mathrm{~cm}$, and $7.50 \mathrm{~cm}$ ) and a width of $7.5 \mathrm{~cm}$, following a saw pattern used for small-diameter trees in Costa Rica (Moya 2004). A total of 20 kiln samples (three $\mathrm{x}$ thick board) per species were weighed every three days until reaching constant values (Rietz and Page 1971). The drying rate was defined as the time needed to reach $20 \%$ of moisture content and was categorized as slow, moderate, and fast, according to the Pan-American Committee of Testing Norms for tropical species (Comisión Panamericana de Normas y Estándares 1976).

Preservation and decay resistance. A total of 20 samples per species with dimensions of $5 \times 5 \times 5 \mathrm{~cm}$ were systematically taken from the sapwood and the heartwood sections of each $\log$ and treated with CCA (chrome, copper and arsenic) preservatives at $2.8 \% \mathrm{vv} / \mathrm{vv}$ concentration. All samples were placed into an experimental preservation tank under a pressure of $690 \mathrm{kPa}$ (approximately $100 \mathrm{psi}$ ), according to CCA preservation methods (AWPA 1981). Curcuma stain was applied to the cross sections for identifying the areas conducting the preservatives. The samples were weighed before and after the preservation process. The preservative retention was given by the difference in weight while the absorption capacity was calculated as the absorption of preservatives (liters) by timber volume $\left(\mathrm{m}^{3}\right)$.

Three samples per tree were cut for decay determination (30 per species) of $20 \times 20 \times 20 \mathrm{~mm}$ size in radial pattern (pith-to-bark direction and systematically distributed) from the cross-sectional samples taken at $1.3 \mathrm{~m}$ high, following ASTM D2017-81 procedures (ASTM 2003c).
Heartwood was not present in T. amazonia, consequently only sapwood samples were obtained for the analyses. As control replicates, three additional samples were randomly selected from each species.

The decay resistance of wood from natural forest trees was compared with that of trees from plantation forests. For this purpose, wood samples were taken from timber (harvested from natural forests) available at local sawmills and analyzed following similar procedures. For each species, a cross-sectional disk was cut from a log and 30 samples of $20 \times 20 \times 10 \mathrm{~mm}$ were obtained randomly from each disk.

The white-rot fungi Trametes versicolor (L. Fr.) was used for the natural durability test in laboratory conditions (accelerated test) following ASTM procedures (ASTM 2003c). The relative resistance of each test block to decay was measured as the loss percentage of oven dry weight during a 12-week exposure to fungi.

Statistical analyses. A general statistical description (average and variation coefficient) was performed for the different variables. An analysis of variance (ANOVA) was used to test differences among fast growth plantation species for physical properties (green density, moisture content, specific gravity), mechanical properties (modulus of rupture and modulus of elasticity in flexion, compression parallel to grain, shear parallel to grain and side Janka hardness test) and preservation parameters. Mean differences between species were evaluated using Tukey test $(P<0.01)$. The wood properties evaluated (heartwood, sapwood, and bark percentage) by tree height were applied regression analyses, where stem height was independent factor and wood properties was dependent factor. This relation is demonstrated by scatter plot graphic, where relation coefficient is shown. Analysis of variance (ANOVA) was used for evaluating differences between trees from natural and plantation forests. Where statistical differences occurred, the mean was compared using the Dunnet test $(P<0.01)$.

\section{RESULTS}

Esthetic properties and general wood characteristics. Heartwood content, which was absent in T. amazonia trees, appeared in the other two species with a remarkable darker color in relation to sapwood. All wood esthetic properties are detailed in table 2.

The largest heartwood diameter $(13.1 \mathrm{~cm})$ was found in $V$. guatemalensis at the base of the tree and disappearing completely at $7.5 \mathrm{~m}$ high. The heartwood proportion represented approximately $60 \%$ of the cross sectional area at the base of the tree, decreasing significantly with stem height (figure 1A). Hyeronima alchorneoides presented approximately $30 \%$ of heartwood content, decreasing significantly as well with stem height and disappearing at $3.0 \mathrm{~m}$ high (figure $1 \mathrm{~B}$ ). 
Table 2. General wood characteristics for Terminalia amazonia, Vochysia guatemalensis, and Hyeronima alchorneoides developed in fast-growing condition.

Características generales de Terminalia amazonia, Vochysia guatemalensis y Hyeronima alchorneoides provenientes de plantaciones de rápido crecimiento.

\begin{tabular}{llll}
\hline Wood characteristic & $\begin{array}{l}\text { Terminalia } \\
\text { amazonia }\end{array}$ & $\begin{array}{l}\text { Hyeronima } \\
\text { alchorneoides }\end{array}$ & Vochysia guatemalensis \\
\hline $\begin{array}{l}\text { Heartwood presence } \\
\text { Sapwood and heartwood } \\
\text { demarcation }\end{array}$ & Absent & $\begin{array}{l}\text { Distinct } \\
\text { Boundary distinct: } \\
\text { heartwood colour darker } \\
\text { than sapwood colour }\end{array}$ & $\begin{array}{l}\text { Distinct } \\
\text { Boundary distinct: heartwood } \\
\text { colour darker than sapwood } \\
\text { colour }\end{array}$ \\
Sapwood color & Basically yellow or pale & Lightly red & Basically white \\
Heartwood color & - & $\begin{array}{l}\text { Basically light brown or } \\
\text { shades of brown }\end{array}$ & Light red or reddish \\
Odor & Indistinct & Indistinct \\
Luster & Indistinct & Indistinct & Indistinct \\
Texture & Fine & From medium to fine & Indistinct \\
Lightness & Low & Low coarse \\
Grain wood & Typically straight in & Interlocking & Low \\
direction & Boundaries indistinct & Boundaries indistinct & Typically straight in \\
Growth ring & & & Boundaries indistinct \\
\hline
\end{tabular}

Sapwood content ranged between 55 and $96 \%$ of the cross-sectional area in H. alchorneoides and between 15 and $76 \%$ in V. guatemalensis. As mentioned previously, no heartwood was found in T. amazonia. Bark content ranged between 4.0 and $8.0 \%$ of the cross-sectional area in H. alchorneoides (figure 1A), between 5.0 and $9.0 \%$ in V. guatemalensis (figure 1B), and between 4.0 and $9.0 \%$ in T. amazonia.

The bark proportion remained almost constant (without a clear tendency) for H. alchorneoides (figure 1B) and $T$. amazonia (figure $1 \mathrm{C}$ ) and a statistically significant increment was found only for bark proportion in $V$. guatemalensis (figure 1A).

Physical and mechanical wood properties. The lowest green density $\left(849 \mathrm{~kg} / \mathrm{m}^{3}\right)$ and green moisture $(62.9 \%)$ was found in T. amazonia, while the highest values of green density $\left(1,013 \mathrm{~kg} / \mathrm{m}^{3}\right)$ and green moisture $(177.4 \%)$ corresponded to $H$. alchorneoides and $V$. guatemalensis, respectively. The specific gravity of $V$. guatemalensis was significantly lower than $T$. amazonia and $H$. alchorneoides, evidenced by the significantly low values of mechanical properties. On the contrary, T. amazonia showed statistical difference in specific gravity with $H$. alchorneoides: a highest values of specific gravity was found in T. amazonia (table 3).

Drying capacity. The initial moisture content was highest in $V$. guatemalensis, ranging between 112 and $168 \%$. The moisture content in H. alchorneoides ranged between 95 and $120 \%$, while T. amazonia reached between 51 and 66\% (table 4).

The moisture content decreased with an increment of the board thickness. The thinnest boards $(1.2 \mathrm{~cm})$ dried the fastest and reached 20\% moisture content in 14-21 days, while the thickest boards $(7.5 \mathrm{~cm})$ dried the lowest and reached 20\% moisture content in 38-100 days. Boards of $3.75 \mathrm{~cm}$ and thicker of $V$. guatemalensis required a greater number of days for reaching $20 \%$ moisture content than those of $H$. alchorneoides and $T$. amazonia (figure 2).

Damages caused by insects and fungi were found during the air drying of boards. H. alchorneoides was the most resistant species, followed by $V$. guatemalensis with minor damages caused by fungi. T. amazonia was attacked by insects.

Preservative uptake. The heartwood of $V$. guatemalensis and $H$. alchorneoides showed a very low or null absorption and retention of preservatives, so heartwood of these woods were impermeable to pressurized preservation treatment. The sapwood of all three species was easily permeable, presenting an absorption capacity of $90-325 \mathrm{~L} / \mathrm{m}^{3}$ (table 4). Vochysia guatemalensis showed the highest absorption and retention capacity, followed by $H$. alchorneoides and T. amazonia. Statically significant differences were determined between $V$. guatemalensis and $H$. alchorneoides and T. amazonia, but no difference was found between H. alchorneoides and T. amazonia (table 5). 

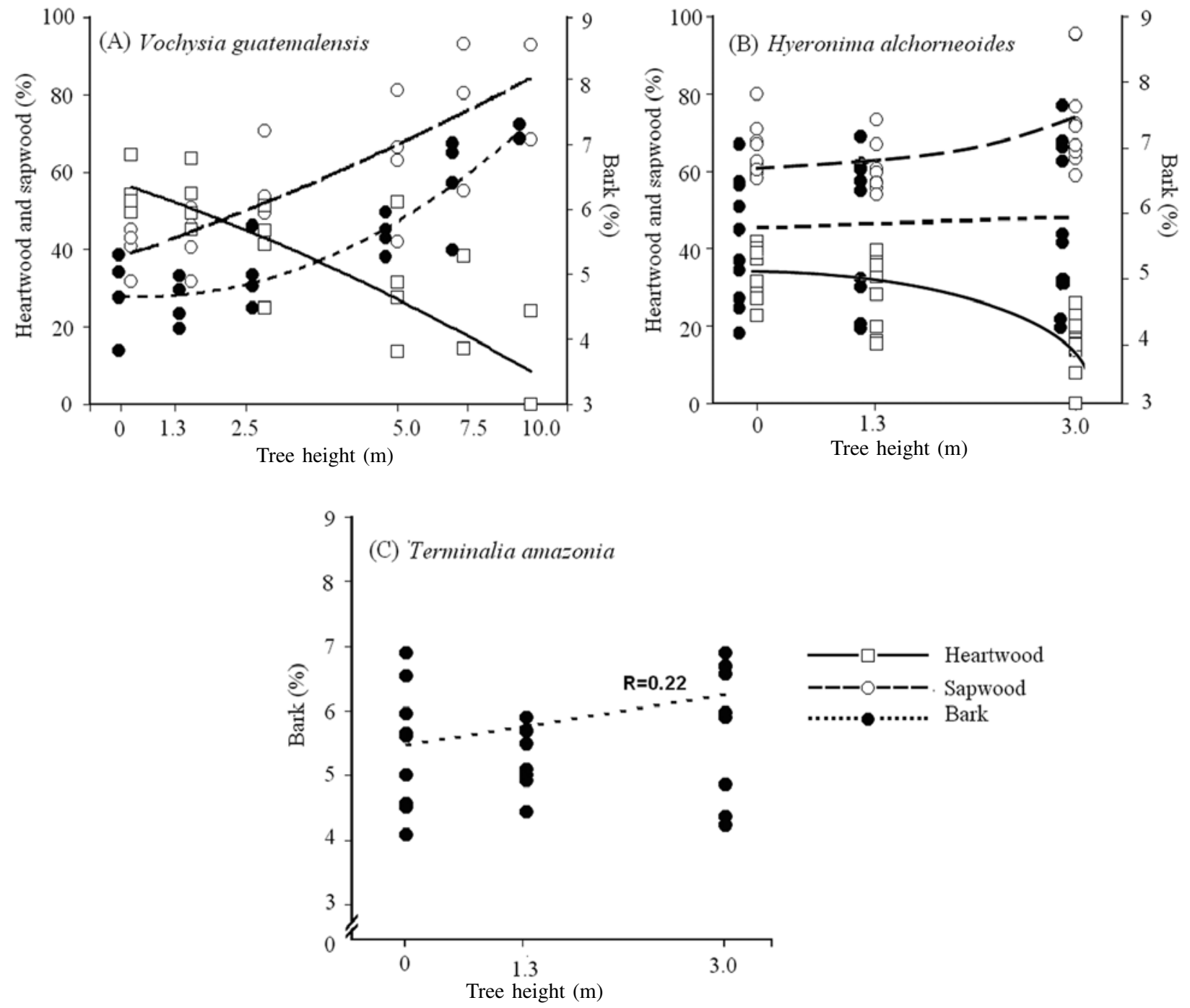

Figure 1. Heartwood, sapwood, and bark proportions with stem height in Vochysia guatemalensis (A), Hyeronima alchorneoides (B), and Terminalia amazonia (C) plantation trees from Costa Rica.

Porcentaje de duramen, albura y corteza en relación a la altura del árbol de plantaciones de Vochysia guatemalensis (A), Hyeronima alchorneoides (B) y Terminalia amazonia (C) en Costa Rica.

Table 3. Physical and mechanical properties of Terminalia amazonia, Vochysia guatemalensis, and Hyeronima alchorneoides plantations in Costa Rica [Mean (CV\%)]. Costa Rica

Propiedades físicas y mecánicas de plantaciones de Terminalia amazonia, Vochysia guatemalensis y Hyeronima alchorneoides en

\begin{tabular}{|c|c|c|c|c|}
\hline \multicolumn{2}{|c|}{ Wood property } & Terminalia amazonia & Vochysia guatemalensis & Hyeronima alchorneoides \\
\hline \multicolumn{2}{|l|}{ Specific gravity $\left(\mathrm{g} / \mathrm{cm}^{3}\right)$} & $0.52^{\mathrm{a}}(9.91)$ & $0.33^{b}(3.67)$ & $0.48^{\mathrm{c}}(8.86)$ \\
\hline \multicolumn{2}{|l|}{ Green density $\left(\mathrm{kg} / \mathrm{m}^{3}\right)$} & $849^{\mathrm{a}}(8.71)$ & $905^{\mathrm{a}}(3.38)$ & $1013^{\mathrm{b}}(4.44)$ \\
\hline \multicolumn{2}{|c|}{ Green moisture $(\%)$} & $62.9^{\mathrm{a}}(16.5)$ & $177.4^{\mathrm{b}}(7.9)$ & $111.3^{\mathrm{c}}(11.9)$ \\
\hline \multicolumn{2}{|c|}{ Compression parallel to grain $\left(\mathrm{kg} / \mathrm{m}^{2}\right)$} & $437.7^{\mathrm{a}}(11.6)$ & $274.7^{\mathrm{b}}(5.9)$ & $\left.493.1^{\mathrm{c}} 9.2\right)$ \\
\hline \multicolumn{2}{|c|}{ Shear parallel to grain $\left(\mathrm{kg} / \mathrm{m}^{2}\right)$} & $142.0^{\mathrm{a}}(13.8)$ & $96.6^{\mathrm{b}}(9.6)$ & $141.3^{\mathrm{a}}(16.1)$ \\
\hline \multirow{2}{*}{ Janka hardness $\left(\mathrm{kg}\left(\mathrm{m}^{2}\right)\right.$} & End & $688.0^{\mathrm{a}}(16.0)$ & $348.2^{\mathrm{b}}(14.8)$ & $724.9^{\mathrm{c}}(12.0)$ \\
\hline & Side & $601.5^{\mathrm{a}}(8.5)$ & $297.6^{\mathrm{b}}(13.2)$ & $614.6^{\mathrm{a}}(14.9)$ \\
\hline \multirow[t]{2}{*}{ Static bending $\left(\mathrm{kg}\left(\mathrm{m}^{2}\right)\right.$} & MOR & $780.7^{\mathrm{a}}(29.5)$ & $478.6^{\mathrm{b}}(14.2)$ & $892.5^{\mathrm{c}}(13.9)$ \\
\hline & MOE & $100,795^{\mathrm{a}}(28.2)$ & $60,390^{\mathrm{b}}(21.8)$ & $116,995^{\mathrm{c}}(14.3)$ \\
\hline
\end{tabular}

Where, $\mathrm{MOR}=$ modulus of rupture; $\mathrm{MOE}=$ modulus of elasticity; $\mathrm{CV}=$ coefficient of variation. Different letters in different species are different statistically at $99 \%$. 
Table 4. Air-dried characteristics of Terminalia amazonia, Vochysia guatemalensis and Hyeronima alchorneoides from forest plantations in Costa Rica. Costa Rica.

Características de secado al aire de plantaciones de Terminalia amazonia, Vochysia guatemalensis y Hyeronima alchorneoides en

\begin{tabular}{|c|c|c|c|c|c|c|c|c|c|}
\hline \multirow[b]{2}{*}{$\begin{array}{l}\text { Thickness } \\
(\mathrm{cm})\end{array}$} & \multicolumn{3}{|c|}{ Vochysia guatemalensis } & \multicolumn{3}{|c|}{ Terminalia amazonia } & \multicolumn{3}{|c|}{ Hyeronima alchorneoides } \\
\hline & $\begin{array}{c}\mathrm{IMC} \\
(\%)\end{array}$ & $\begin{array}{l}\text { Number of } \\
\text { days* }\end{array}$ & $\begin{array}{l}\text { Drying rate } \\
(\% / \text { day })\end{array}$ & $\begin{array}{c}\mathrm{IMC} \\
(\%)\end{array}$ & $\begin{array}{l}\text { Number of } \\
\text { days* }\end{array}$ & $\begin{array}{l}\text { Drying rate } \\
(\% / \text { day })\end{array}$ & $\begin{array}{c}\mathrm{IMC} \\
(\%)\end{array}$ & $\begin{array}{l}\text { Number of } \\
\text { days* }\end{array}$ & $\begin{array}{l}\text { Drying rate } \\
\text { (\%/day) }\end{array}$ \\
\hline 1.2 & 139 & 14 & 9.9 & 51 & 21 & 2.4 & 95 & 21 & 4.5 \\
\hline 2.5 & 112 & 31 & 3.6 & 61 & 29 & 2.1 & 110 & 35 & 3.1 \\
\hline 3.8 & 122 & 63 & 1.9 & 54 & 29 & 1.9 & 115 & 49 & 2.4 \\
\hline 5.0 & 127 & 70 & 18 & 66 & 32 & 21 & 100 & 56 & 1.8 \\
\hline 6.2 & 154 & 90 & 1.7 & 47 & 35 & 1.3 & 120 & 63 & 1.9 \\
\hline 7.5 & 168 & 100 & 1.7 & 53 & 38 & 1.4 & 117 & 70 & 1.7 \\
\hline
\end{tabular}

Where: IMC = initial moisture content and *number of days for reaching $20 \%$ moisture content.

Table 5. Penetration, absorption and retention capacity of Terminalia amazonia, Vochysia guatemalensis and Hyeronima alchorneoides trees from forest plantations in Costa Rica.

Penetración, absorción y retención en plantaciones de Terminalia amazonia, Vochysia guatemalensis y Hyeronima alchorneoides en Costa Rica.

\begin{tabular}{|c|c|c|c|c|c|}
\hline \multirow{2}{*}{ Species } & \multicolumn{2}{|c|}{ Penetration on } & \multicolumn{3}{|c|}{ Preservative uptake in sapwood } \\
\hline & Sapwood & Heartwood & Parameter & Absorption $\left(\mathrm{L} / \mathrm{m}^{3}\right)$ & Retention $\left(\mathrm{kg} / \mathrm{m}^{3}\right)$ \\
\hline Vochysia & Yes & No & Mean & $325^{\mathrm{a}}$ & $9.0^{\mathrm{a}}$ \\
\hline guatemalensis & & & CV\% & 9.5 & 12.5 \\
\hline Terminalia & Yes & & Mean & $89.5^{b}$ & $2.5^{\mathrm{b}}$ \\
\hline amazonia & & - & CV\% & 14.2 & 14.2 \\
\hline $\begin{array}{l}\text { Hyeronima } \\
\text { alchorneoides }\end{array}$ & Yes & No & $\begin{array}{l}\text { Mean } \\
\text { CV\% } \\
\mathrm{N}\end{array}$ & $\begin{array}{l}100.7^{\mathrm{b}} \\
26.4 \\
20\end{array}$ & $\begin{array}{l}2.8^{\mathrm{b}} \\
26.4 \\
20\end{array}$ \\
\hline
\end{tabular}

Different letters in different species are different statistically at $99 \%$.

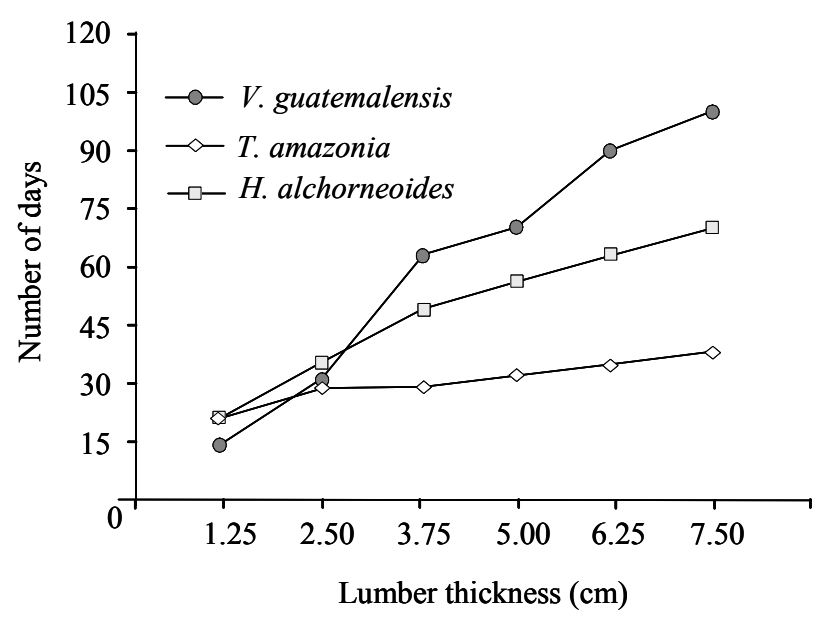

Figure 2. Number of days for reaching $20 \%$ moisture content at different lumber thicknesses in Vochysia guatemalensis, Hyeronima alchorneoides and Terminalia amazonia plantation trees from Costa Rica.

Número de días para alcanzar el 20\% de contenido de humedad para diferentes espesores de madera en plantaciones de Terminalia amazonia, Vochysia guatemalensis y Hyeronima alchorneoides en Costa Rica.
Decay resistance. Dry weight loss in wood coming from natural stands was compared with that coming from forest plantations. It was carried out for the variable dry weight loss, commonly considered as an indicative of decay resistance to fungi. In general, sapwood tissues lost more weight than heartwood tissues, both from plantation as well as from natural stands.

In terms of sapwood, T. amazonia from natural forest presented the highest weight loss $(31.5 \%)$ and the second highest weight loss from forest plantations (25.6\%), as shown in figure 3A. Vochysia guatemalensis samples from plantation trees had the highest weight loss $(27.1 \%)$, while natural forest samples reduced their weight only by $2.2 \%$ (figure 3B). Hyeronima alchorneoides showed the lowest value of weight loss for forest plantations (10.9\%), while the samples from natural stands reached a middle value of $7.4 \%$ (figure $3 \mathrm{C}$ ).

In terms of heartwood, $V$. guatemalensis samples from plantation trees had the highest weight loss (23.0\%), while natural forest samples reduced their weight only by $0.5 \%$. Hyeronima alchorneoides showed the lowest value of weight loss for forest plantations (5.8\%), while the samples from natural stands reached a middle value of $3.6 \%$. 

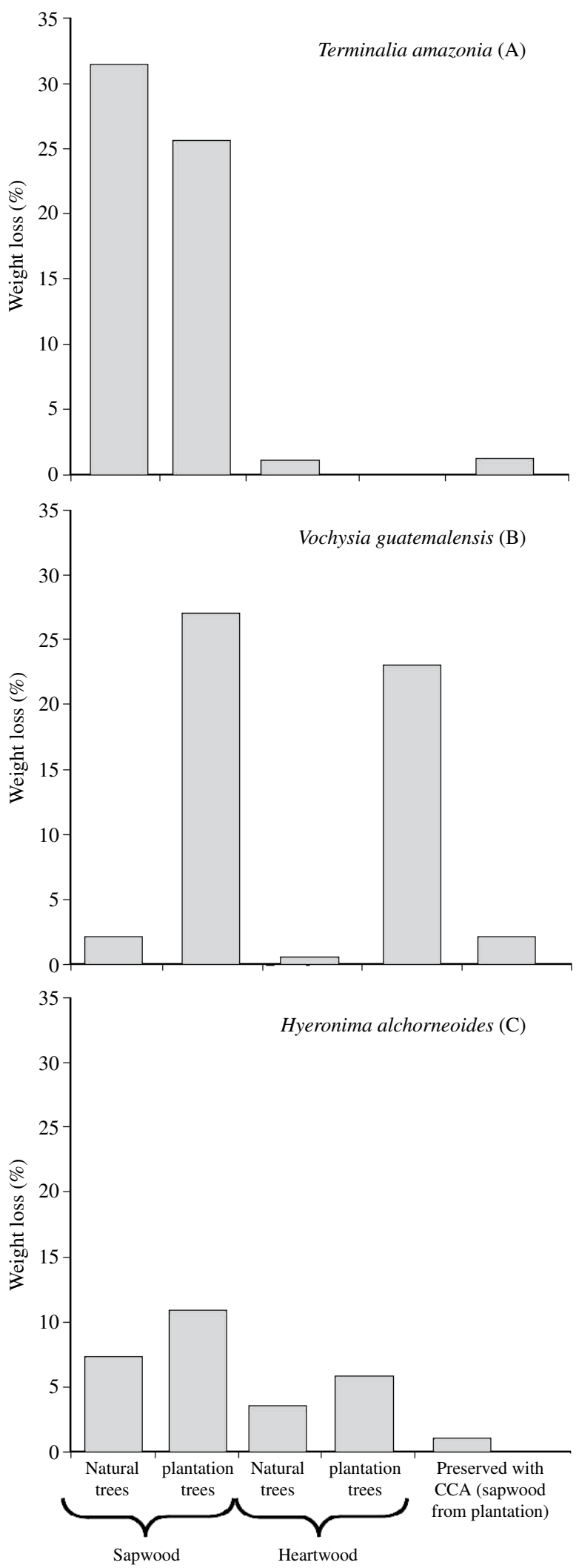

Figure 3. Weight loss caused by Trametes versicolor on Terminalia amazonia (A), Vochysia guatemalensis (B), and Hyeronima alchorneoides (C) plantation trees from Costa Rica.

Pérdida de peso causado por Trametes versicolor en plantaciones de Terminalia amazonia (A), Vochysia guatemalensis (B) y Hyeronima alchorneoides (C) en Costa Rica.
A preservation treatment increased considerably the decay resistance of sapwood to fungi in forest plantation samples, as the dry weight loss was lower than in samples without preservatives. Terminalia amazonia and $V$. guatemalensis reduced their weight loss from over $25 \%$ to less than $2.5 \%$. Hyeronima alchorneoides showed a proportionally significant reduction in dry weight loss (5.8 to $1.1 \%)$.

\section{DISCUSSION}

The estimation of heartwood content helps define differences in durability and other wood characteristics, while specific gravity is considered as an indicator of timber strength (Wiemann and Williamson 1989, Bhat 1995). Low heartwood content with a light brown color was found in $V$. guatemalensis and $H$. alchorneoides, decreasing rapidly with tree height in plantation trees, while natural forest trees studied by González et al. (1973) showed darker heartwood and covered up to $90 \%$ of the cross-sectional area. The age difference between young plantation of less than 10 years and natural forests of over 40 years is suspected to be the main reason explaining the differences in heartwood content. The change in color between sapwood and heartwood is presumed to be due to oxidation and polymerization of phenolics components in heartwood by chemical or enzymatic process and they are increased by tree aging (Gierlinger et al. 2004).

The heartwood proportions among species were found, heartwood was presented in V. guatemalensis and $H$. alchorneoides, but not $T$. amazonia (figure 1). These differences can be influenced by genetic factors. Difficulties in the determination of the time (age) for heartwood formation have been discussed by many researches (Taylor et al. 2002). However, a majority consider that heartwood formation lags behind the growth of the pith and new sapwood layers by a time mostly governed by genetic differences between species.

$V$. guatemalensis timber can be associated to a low strength resistance and pulping production, expected due to its low specific gravity found in this research. Consequently, this species must be used for non-structural purposes. On the contrary, $T$. amazonia and $H$. alchorneoides posses a high specific gravity and superior mechanical properties (table 2), which gives to the species a reputation of high resistant for structural uses (Solis and Moya 2004abc).

Green density can be associated to fresh sawn timber and the consequent ease of manipulation in the industrial process. T. amazonia presented the lowest green density and its drying rate was the lowest at any lumber thickness, suggesting that the species is very convenient for transportation and drying processes.

Previous studies on wood mechanical properties of forest species in Latin America suggest a great variability among species and countries (Solis and Moya 2002abc). T. amazonia trees from natural forests in Panama (Llach 
1971), Nicaragua (González et al. 1973), Bolivia, Venezuela and Colombia (Keenan and Tejada 1987), among others, are reported to have superior mechanical properties than those of forest plantations evaluated in trees from plantation.

In the case of $V$. guatemalensis and H. alchorneoides, considerable differences are found in the literature. Studies on V. guatemalensis growing in natural forests in La Ceiba (Honduras) carried out by Sotela and Carpio (1991) report lower mechanical properties than those in forest plantations found in the present study. On the contrary, similar studies carried out in Panama (Llach 1971), Nicaragua (González et al. 1973), and Costa Rica (Tuk 1980) report higher values than our results with plantations trees. Studies on trees of $H$. alchorneoides done by Tuk (1980) and Benítez and Montesinos (1988) in the Atlantic zone of Costa Rica and La Ceiba (Honduras), respectively, report lower mechanical properties than for plantation trees in Costa Rica. In Panama (Llach 1971) and Nicaragua (González et al. 1973), superior mechanical properties were found in natural forest trees, suggesting a general influence of site and environmental conditions on wood quality. Zobel and Van Buijtenen (1989) suggest that large structure variations are produced by changes in climate, site, and management characteristics, as product of these extrinsic factors influencing the cambial activity.

The drying rate increased with increasing board thickness (figure 2), following the common rule of proportionality (Rietz and Page 1971). The water in lumber moves from high to low moisture content zones, aiming at a moisture equilibrium through-out the board. This means that the drying within a board occurs from its interior, moving the moisture to drier surfaces more rapidly in thinner boards. The difference in drying time among species with different board thicknesses can be attributed to initial moisture content. The initial or green moisture content showed a positive correlation with air-drying time. The fastest drying rate was found in T. amazonia, followed by $H$. alchorneoides with intermediate values and by $V$. guatemalensis with the slowest air-drying rate. However, other inherent wood characteristics can affect drying time, such as vessels and parenchyma rays compositions (Skaar 1972), but they were not considered in this research.

The sapwood presented a good absorption and retention capacity (table 5). However, all samples were susceptible to Trametes versicolor. Terminalia amazonia from natural and plantation forests and V. guatemalensis from plantation forest showed the highest weight loss percentages (figure 3 ). Hyeronima alchorneoides samples from both growing conditions showed a moderate resistance. Sapwood samples from forest plantations treated with CCA preservative showed a similar decay resistance than heartwood samples from natural forests because sapwood were totally treated with preservative. These results confirm the need to protect both natural and plantation timber from fungi, particularly for those species with high weight loss (Bhat et al. 2005).
According to ASTM D-2017-81 standards (ASTM 2003c) the heartwood of 9-year-old $H$. alchorneoides trees are graded as Class I (highly resistant), while $V$. guatemalensis heartwood is graded as Class III (moderately resistant). Similarly, the sapwood of T. amazonia and $V$. guatemalensis trees from forest plantations are graded as Class III (moderately resistant) and $H$. alchorneoides as Class II (resistant). Highly resistant timber (durability Class I) was obtained when sapwood was treated with CCA preservatives in all three species.

The growing conditions in plantations are generally more favorable compared with those in virgin forests. This may result in high growth rates. Some studies have shown that trees from plantations produce poor quality wood compared to wood from trees grown in the natural forest (Butterfield et al. 1993, Monique et al. 1994, Bosman 1996, Bauch and Dünish, 2000). Heartwood proportions, esthetic, physical and mechanical characteristics, and durability found in $V$. guatemalensis, $H$. alchorneoides are consistent with these studies. However, some mechanical wood properties of $V$. guatemalensis and T. amazonia were same in trees from natural forest and plantation.

\section{CONCLUSIONS}

Young trees of $V$. guatemalensis, T. amazonia, and $H$. alchorneoides show different esthetic characteristics in comparison to expectations in the market, particularly due to the reduced heartwood content and its light dark color. Consequently, high quality timber should not be expected from plantations younger than 10 years.

Preliminarily, it can be stated that wood from young plantation trees of $V$. guatemalensis, T. amazonia, and $H$. alchorneoides in Costa Rica show inferior wood properties than trees from natural forests. It was found that specific gravity and mechanical properties of plantation were inferior than wood from reports data with trees from natural forests. Terminalia amazonia from young forest plantations showed very promising characteristics for industry processes due to its ease of drying, manipulation, and mechanical properties. Considerable differences are found in the literature in relation to physical and mechanical properties for $V$. guatemalensis and $H$. alchorneoides.

Heartwood of young trees of $H$. alchorneoides is graded as highly resistant, while V. guatemalensis heartwood is graded as moderately resistant. Similarly, the sapwood of T. amazonia and $V$. guatemalensis young trees are graded moderately resistant and $H$. alchorneoides sapwood resistant. However, the natural durability of species (young or mature) from humid regions of Costa Rica can be increased by means of preservation techniques such as the vacuumpressing method, which are very convenient particularly in young trees with high content of sapwood. 


\section{ACKNOWLEDGMENTS}

The authors wish to thank Vicerrectoría de Investigación y Extensión at the Instituto Tecnológico de Costa Rica for financial support.

\section{REFERENCES}

Alice F, F Montagnini, M Montero. 2004. Productividad en plantaciones puras y mixtas de especies forestales nativas en la Estación Biológica La Selva, Sarapiquí, Costa Rica. Agronomía Costarricense 28(2): 61-71.

ASTM (American Society for Testing and Materials, US). $2003 \mathrm{a}$. Standard test methods for specific gravity of wood and wood-base materials. ASTM D 2395-02. 15 p.

ASTM (American Society for Testing and Materials, US). $2003 \mathrm{~b}$. Test Methods for Small Clear Specimens of Timber. ASTM D 143-94 Reproved 2000. 40 p.

ASTM (American Society for Testing and Materials, US). 2003c. Standard method of accelerated laboratory test of natural decay resistance of woods. ASTM D 2017-81 Reproved 1994. $12 \mathrm{p}$.

AWPA (American Wood Preserves Association, US). 1981. Determining penetration of preservatives and fire-retardants. AWPA A3-1980. 6 p.

Bauch J, O Dünish. 2000. Comparison of growth dynamics and wood characteristics of plantations-grown and primary forest Carapa guianensis in Central Amazonia. IAWA $J$ 21: 321-333.

Benítez RF, JL Montesinos. 1988. Catálogo de cien especies forestales de Honduras: Distribución, propiedades y usos. Honduras. Escuela Nacional de Ciencias Forestales (ESNACIFOR). 213 p.

Bhat KM. 1995. A note on heartwood proportion and wood density of 8-year-old teak. Indian Forester 121 (6): 514-516.

Bhat KM, PK Thulasides, EJ Florence. 2005. Wood durability of home-garden teak against brown-rot and white-rot. Trees 19: 654-660.

Butterfield R, RP Crook, R Adams, R Morris. 1993. Radial variation in wood specific gravity, fiber length and vessel area for two Central American hardwoods; Hyeronima alchorneoides and Vochysia guatemalensis: natural and plantation-grown trees. IAWA $J$ 17: 5-14.

Bosman MTM. 1996. Longitudinal variation in selected wood properties of naturally and plantation grown Light Red Meranti (Shorea leprosula and S. parvifolia, Dipterocarpaceae). IAWA $J$ 17: 55-64.

Calvo J, D Arias, A Sibaja. 1996. Evaluación de un ensayo de procedencia-progenie para Terminalia amazonia a los doce meses de edad en la zona norte de Costa Rica. En Memoria del IV Taller Nacional de Investigación Forestal y Agroforestal. Guácimo, Limón, Costa Rica, 1-7, Julio, 1996. p. 15-18.

Comisión Panamericana de Normas y Estándares. 1976. Normas y metodología para las actividades tecnológicas. PADTREPORT. Pacto Andino Proyecto Andino de Desarrollo Tecnológico en el área de recursos forestales tropicales. Colombia. 78 p.
Gierlinger N, D Jacques, M Gradner, R Wimmer, M Schwanninger, P Rozenberg, LE Pâques. 2004. Colour of larch heartwood and relationships to extractives and brown-rot decay resistance. Trees 18: 102-108.

González EJ, RF Fisher. 1994. Growth of native forest species planted on abandoned pasture land in Costa Rica. Forests Ecology and Management 70: 159-167.

González E, R Fisher. 1998. Variation in selected wood properties of Vochysia guatemalensis from four sites in Costa Rica. Forest Science 44: 185-191.

González G, C Wiessel, R Chavarri. 1973. Propiedades y usos de quince especies maderables del nordeste de Nicaragua. Informe Técnico 9. Colombia. Programa para las Naciones Unidas FO: SF/NIC 9. 202 p.

Holdridge LR. 1967. Life Zone Ecology. Tropical Science Center San José, Costa Rica. 331 p

IAWA-Committee. 1989. List of microscopic features for hardwood identification. IAWA Bulletin. 10: 226-332.

Keenan FJ, M Tejada. 1987. Maderas tropicales como material de construcción en los países del grupo andino de América del Sur. Ottawa, Canadá. Centro Internacional de Investigaciones para el Desarrollo. 147 p.

Llach L. 1971. Propiedades físicas y mecánicas de ciento trece especies maderables de Panamá. Parte 3. Curridabat-Costa Rica. Laboratorio de Productos Forestales. Universidad de Costa Rica. 752 p.

Monique TM, I Bosman, K ven Genderen, P Baas, 1994. Radial variation in wood properties of naturally and plantation grown light red meranti (Shorea, dipterocarpaceae). IAWA J 15: 111-120

Montagnini F. 2000. Accumulation in aboveground biomass and soil storage of mineral nutrients in pure and mixed plantations in a humid tropical lowland. Forests Ecology and Management 134: 257-270.

Montagnini F. 2001. Strategies for the recovery of degraded ecosystems: experiences from Latin America. Interciencia 26: 498-503.

Montagnini F, C Porras. 1998. Evaluating the role of plantations as carbon sinks: an example of an integrative approach from the humid tropics. Environment Management 22: 459-470.

Mora F. 2002. La reforestación con especies nativas en Costa Rica: un recuento histórico. In Instituto de Investigaciones y Servicios Forestales (INISIFOR) . Memoria del TallerSeminario Especies Forestales Nativas, Universidad Nacional de Costa Rica, Heredia, Costa Rica, 4-5 Abril, 2002.

Moya R. 2000. Comportamiento y rendimiento en aserrío de trozas de Terminalia amazonia de 6 años de edad provenientes de la zona sur de Costa Rica. Revista Forestal Centroamericana 29(1): 14-19.

Moya R. 2004. Wood of Gmelina arborea in Costa Rica. New Forest 28: 299-307.

Murillo O, G Obando, J Badilla, S Sánchez. 2001. Perspectivas en las zonas altas de Costa Rica. Biocenosis 15(1-2): 66-71.

Pérez D, M Kanninen. 2001. Stand growth scenarios for Bombacopsis quinata plantations in Costa Rica. Forests Ecology and Management 177: 427-439.

Petit B, F Montagnini. 2004. Growth equations and rotation ages of ten native tree species in mixed and pure plantations in the humid neotropics. Forests Ecology and Management 199: 243-257. 
Piotto D, F Montagnini, L Ugalde, M Kanninen. 2003. Performance of forest plantations in small and medium sized farms in the Atlantic lowlands of Costa Rica. Forest Ecol. Manag. 175: 195-204.

Rietz R, R Page. 1971. Air Drying of lumber: A guide to industry practices. Wisconsin, USA. U.S. Department of Agriculture. Forest Service. 402 p. Agriculture Handbook No. 402.

Skaar C. 1972. Water in wood. Syracuse wood Science series, 4. New Cork. Syracuse University Press. 218 p.

Solis M, R Moya. 2004a. Hyeronima alchorneoides en Costa Rica. Fondo Nacional de Financiamiento San José, Costa Rica. Fondo Nacional de Financiamiento Forestal. Ministerio de Energía y Minas. Gobierno de Costa Rica. 106 p

Solis M, R Moya. 2004b. Teminalia amazonia en Costa Rica. San José, Costa Rica. Fondo Nacional de Financiamiento Forestal. Ministerio de Energía y Minas. Gobierno de Costa Rica. $113 \mathrm{p}$

Solis M, R Moya. 2004c. Vochysia guatemalensis en Costa Rica. San José, Costa Rica. Fondo Nacional de Financiamiento
Forestal. Ministerio de Energía y Minas. Gobierno de Costa Rica. 107 p.

Sotela J, MI Carpio. 1991. Vochysia guatemalensis en Centroamérica. Informe INII-63-1991. Laboratorio de Productos Forestales. Curridabat -Costa Rica. Instituto de Investigaciones en Ingeniería. Universidad de Costa Rica. 22 p.

Tuk J. 1980. Clasificación y Normalización de Maderas para uso estructural. Cartago, Costa Rica. Informe General del Proyecto. Centro de Investigaciones de Ingeniería en Maderas. Cartago, Costa Rica. Instituto Tecnológico de Costa Rica. 101 p.

Wiemann MC, GB Williamson. 1989. Wood specific gravity gradients in tropical dry and montane rain forest trees. American Journal Botany 76(6): 924-928.

Zobel BJ, B van Buijtenen. 1989. Wood variation: Its causes and Control. New York, USA. Springer Verlag. 363 p.

Recibido: 09.12.08

Aceptado: 25.03.09 